\title{
Readers' Perception and Comprehension on the English Translation of Radya Pustaka Museum
}

\author{
Bayu Budiharjo ${ }^{1}$, Ida Kusuma Dewi², Dyah Ayu Nila Khrisna ${ }^{3}$, M. R. Nababan ${ }^{4}$ \\ \{budiharjo_b@staff.uns.ac.id ${ }^{1}$, ida.k.d@staff.uns.ac.id ${ }^{2}$, dahayu@staff.uns.ac.id ${ }^{3}$, \\ amantaradja.nababan_2017@staff.uns.ac.id ${ }^{4}$ \}
}

Universitas Sebelas Maret, Surakarta ${ }^{1}$, Universitas Sebelas Maret, Surakarta ${ }^{2}$ Universitas Sebelas Maret, Surakarta ${ }^{3}$, Universitas Sebelas Maret, Surakarta ${ }^{4}$

\begin{abstract}
Brochure as one form of promotional media can be an effective instrument in boosting the rate of visit of a tourism destination. One of the tourism destinations in Surakarta, Radya Pustaka museum, makes use of brochure to attract visitors, both domestic and foreign. The museum therefore makes brochure available in bahasa Indonesia and in the translated version in English. This article attempts to explore the perception of foreign visitors coming to the museum concerning the naturalness of the expressions in the English version of the brochure. The data in this research consist of text in the English version of the museum's brochure. The other form of the data takes form of the result of questionnaire and in-depth interview with ten foreign visitors. The analysis is conducted by applying Miles and Huberman's data analysis. The result of the study can reveal how natural the expressions in the English version of Radya Pustaka museum brochure are, viewed from the target readers' perspectives. Further, the result can be a noteworthy reference for the museum management to improve the quality of the brochure as one of the attempts to attract more foreign visitors and to disseminate information and knowledge about the collection of the museum and the culture of Java.
\end{abstract}

Keywords: Readability, Naturalness, Translation, Tourism, Brochure, Museum

\section{Introduction}

Translation plays an important role in various aspects: entertainment, education, tourism, movie subtitles, brochures, notice boards at tourist attractions and others. Various translated products and works have been reviewed with different focuses.One study in the field of translation that is important to do is the study of translation in the field of tourism. This kind of study is important to do in Indonesia because Indonesia has great number of regions that are well-known as tourist attractions. Various tourist sites such as museums, temples, beaches, parks, located in Bali, Yogyakarta, Solo, and other cities are visited by many tourists, both domestic and foreign. Because many tourist attractions have the potential to attract tourists from outside the regions and from abroad, the management of the attractions needs to provide information related to the places of interest that are managed tourist attractions, such as history and culture. This kind of information must be provided in a language that can be easily understood by and is communicatively presented to tourists.

One of the attractions that needs to provide important information to tourists is Radya Pustaka Museum. Visitors of this museum are not only domestic tourists, but also foreign tourists. Therefore, the information contained in this museum is conveyed in two languages, namely Indonesian and English. The information available at the Radya Pustaka Museum must be ensured to have high validity. The validity of the information is needed because the 
museum is a source of information that is often used as a reference in research, news, entertainment, and various other purposes. Reliable information is not only conveyed in Indonesian because tourists visiting the Radya Pustaka Museum are not only domestic tourists. Thus, the translation of various texts in the museum must be of high quality to ensure information in the target language (English) is equivalent with information in Indonesian. In addition, the element of naturalness of the expressions has a role that is no less important than the aspect of message. The importance of message delivery is related to the number of cultural bound terms contained in texts in the museum, most of which are in Javanese.Therefore, the delivery of messages must be done naturally both in English and in Indonesian.

Research on brochure translation with a focus on equivalents and translation strategies was carried out by Sari and Antoni (n.d.). [1]. Research with a similar focus is research that explores the strategy and inaccuracy of message transfer conducted by Shehab (2011) [2]. Different brochure translation studies were conducted to examine the content of brochures in English-speaking countries which were translated by the target audience of Arabic-speaking countries by Sulaiman (2016) [3]. Another brochure translation study with a different focus, namely the factor of the text features of the Spanish medical brochure translated into English was carried out by Ornia (2015) [4].

The results of this study can reveal the naturalness of translation expressions and the degree to which translation is easily understood directly from the ideal readers of the target language text. Thus, the results of this study play a role in adding concepts in Translation Studies, namely the principles in the translation of brochures and tourism promotion media that have special characteristics. The results of this study can also be used as a reference for translator's decision making in the field of translation practice, especially when translators translate brochures in general as well as museum brochures

\section{Research Methodology}

This research aims to study how natural and understandable the expressions used in the English translation of Radya Pustaka Museum brochure are and how persuasive the text is in the perception of potential tourists. The data cover English verbal text in the brochure, which is translated from Indonesian and the visual content in the brochure functions as the context. The other data take form of statements and comments gained from the informants about how natural, understandable, and persuasive the English translation in the Radya Pustaka Museum brochure is. The verbal text was taken from the brochure and the data reflecting respondents' perception were collected by means of questionnaire, in which the respondents marked the expressions considered to be unnatural and difficult to understand. The data were then analyzed to reveal cases causing the translation to sound unnatural and be difficult to understand. In addition to the investigation of the naturalness and comprehensibility of the English translation, the naturalness of the data in the form of verbal text were analyzed in terms of the grammar used. The level of persuasion was then studied based on the information from the respondents. Lastly, the concluding result was drawn.

\section{Results}

The evaluation of the readability of the Radyapustaka Museum's tourism brochure results in some issues found in the translation that mostly lead to confusion for foreign visitors. The problems can be divided into two categories, namely linguistic issues and cultural issues. 
Linguistic issues are the classification of data containing grammatical errors along with syntactic error, semantic error, and typographical error.

\subsection{Linguistic issues:}

\subsubsection{Syntactic Error}

This deals with the arrangement of words or phrases which are not well-formed in a sentence triggered by the following sources:

a) Determiner absence

The error is noticed in some data which allow "The" as the determiner to exist but cannot be found in the text. Below is one of the examples:

249 Bronze of $7^{\text {th }}$ centuries are exhibited next to ancient Javanese inscription.

It is difficult for readers to understand this clause because of the absence of the determiner to begin the sentence and to refer to the ordinal number, as seen in the phrase "7th century." Also, The determiner should exist before the proper noun of "ancient Javanese inscription" becoming "The 249 Bronze of the $7^{\text {th }}$ centuries are exhibited next to the ancient Javanese inscription.

\section{b) Plural maker absence}

The second type of failure is incorrect pluralization. The noun plural is formed in two ways: regular and irregular. In regular pluralization, we can simply add 's' in nouns having more than one in number, but a bit complex for the irregular pluralization. The following example shows the lack of language proficiency of the translator due to the missing plural marker that should be found in the word of 'collection' signifying the phrase of "481 various wayang collection."

c) Verb absence

A good translation should not sound like a translation. It can only be realized when the text is perfectly grammatical. The errors spotted in the following examples should have never been found in a tourism brochure.

1) The yacht used by the King sri Susuhunan Pakubuwana IV with his wife Kanjeng Ratu Kencana Wungu when traveled bengawan Solo.

2) The sword of King Amangkurat II and Pancasula's spear glowing under the light are displayed in the corridor of the museum.

The grammatical error in the first example is marked with the missing of 'to be' as an auxiliary verb. The sentence is identified as a passive voice since the person doing the action is preceded by the word "by". The presence of "was" is needed to create a correct sentence. 
The second example is hard to comprehend too. The translator appears to literally alter the source language to the target language which causes an absurd translation. This original version "Pedang Amangkurat II dan tombak Pancasula yang bersinar keemasan di bawah cahaya lampu terpajang di ruangan Tosan Aji" will be better translated into "The sparkling sword of King Amangkurat II and the spear of Pancasula are displayed in the corridor of the museum."

\subsubsection{Semantic Error}

The data classified into this category are words, phrases, or clauses which are difficult for the respondents to understand because they are open to more than one interpretation. The following are the examples.

1) The yacht used by the King sri Susuhunan Pakubuwana IV with his wife Kanjeng Ratu Kencana Wungu when traveled bengawan Solo river.

The respondents questioned the circumstances that constitute the setting for the event that describes Kanjeng Ratu Kencana Wungu as she traveled along the Bengawan Solo River. This is not entirely comprehensible because the readers are not presented with a relevant situation background. To develop their understanding, a brief overview of the river trip should be given. Besides, this sentence is grammatically incorrect. It contributes significantly to another muddle. The predicate is missing and it fails to form the gerund of the word 'travel'.

2) The dining set collections of Keraton Surakarta, Mangkunegaran, and Europe are showcase alongside with a "Porcelain Goblet" the prize from Napoleon Bonaparte (1811).

The sentence involves a degree of ambiguity. The incorrect choice of the underlined term leads the readers to obscurity. It is difficult to view the word "prize' in context. The surrounding word and circumstances suggest the use of the term 'gift' or 'present' instead of 'prize', as it was a thing which was freely given without payment or competition.

3) Those worldwide local cultural harmonies will lead you to explore the spectacular local genius.

This example contains the misleading idea, particularly in the phrase "the spectacular local genius" which is translated from '.......mengajak anda menikmati Harmonisasi budaya local yang mendunia.' A translation modulation is identified in the target text since there is a shift in the viewpoint of "local culture" and "local genius." The source text emphasizes 'local culture' as the object of the sentence but changes as the subject of the sentence in the target text. The term 'local genius' is however off the topic. It is irrelevant and uncommon in the target language.

\subsubsection{Typographical Error}

This type of error is found in several parts of the English version of the brochure. One of the examples is identified in the sentence of "A classy Javanese typerwriter is also 
showcased in the center part of the room." The typo is found in the word 'typerwriter' that should consist of letters spelling the word "typewriter". Also, it will be much clearer and more understandable if the phrase is specified into "Javanese font typewriter."

Another example is the term of "yacht-heard" which is found in the sentence "Canthik Rajamala is yacht-heard which is believed to protect the Rajamala yacht from danger." It has puzzled all the respondents because it is completely lost in meaning. As to describe the front part of the ship used by The King of Rajamala, it is expected to be typed "head" instead of "heard."

\section{2. Cultural Issues}

Cultural reference issues are related to the way in which the culture-related items in the source text are adjusted in the target text so that the recipient language readers can understand them. However, there are certain cultural words the translator fails to make and the readers find it hard to grasp the message as seen in the examples below.

The museum was established on Tuesday Kliwon 15 maulud ehe 1820 or October 28th, 1890.

Culture bound terms pose problems in the translation of the brochure. Terms related to traditional (Javanese) calendar system in the translation "Kliwon", "Maulid", and "ehe" evoke sense of oddity in the view of the informants. The sense is still strongly perceived even though additional information (October 28th, 1890) is already made available. Another term raising similar effect is the term "wayang" in the text "There are over 400 ancient Javanese books which contain about Javanese culture such as Wayang (puppets) stories, history of Kerton, Traditional Javanese Medicine, Dance, Music, Horoscope and Stamp."What wayang is and how it looks like do not belong to the informants' cultural insights. The concept of wayang and its representation cannot be set up despite the addition of "puppets" in the translation. This is likely to happen because the term "puppets" refers to different forms and appearances, which vary from one culture to another.

In addition, the failure of the translation is not only prompted by the lack of the translator's competence but also by the poor quality of the source text. Some parts of the text sound clumsy and difficult to understand. It is triggered by some factors as explained in the following.

1. Overloaded sentence

Long, complex sentence can be difficult to read. The following sentence is a good example for explaining the situation.

“481 koleksi berbagai jenis wayang terpasang dengan indah di Museum Radyapustaka yang di padukan dengan satu set gamelan slendro pelog peninggalan K.R.A Sosrodiningrat IV dan gamelan Larasadi yang diciptakan oleh Ki Partowiyono di tahun 1920 mengajak anda menikmati Harmonisasi budaya local yang mendunia"

The overuse 'which' (yang) clauses makes the text too wordy and causes confusion to readers, particularly translators. 
2. Ungrammatical sentence

This can be found in the text " 400 buku jawa kuno yang berisi kekayaan budaya jawa dengan cerita wayang, sejarah keraton, jamu, tari, music gamelan/ karawitan, pakuwon dan buku jawa cap." It does not comply with the Indonesian grammatical rules as the particular subject of the sentence is missing.

\section{Discussion}

The above analysis has shown that there are two major areas disturbing the naturalness of the translation of the brochure. i.e linguistic aspect and cultural aspect. In the linguistic aspect, the absence of a determiner, the absence of plural marker, the absence verb 'be' in passive form and the use of a plural verb for the singular subject are detected. They suggest that the translation does not conform to some aspects of the English language systems. The determiners absence, for example, is a clear indication that the translation does not conform the English linguistic system since in English "A determiner is an obligatory element of a noun phrase, the only other obligatory member of which is the noun itself. A noun cannot appear by itself: it must minimally be preceded by a determiner." (Master, 2013:34) [5]. Conforming to the target language system is one of the characteristics of natural translation.

Not only do the grammatical errors cause the translation unnatural as English sentences, but they also make the translation difficult to understand. The absence of determiners, for example, can make the nouns and the sentences unclear since English determiners work to clarify nouns and make a sentence as precise and focused as possible (Master, 2013: 35-36) [5]. The absence of verb 'be' in passive form, for another example, can create a new meaning that does not make any sense. When the verb 'be' is absence from a passive form, the sentence will look like an active form and the 'recipient' in the subject position will be considered as the 'doer' of the action (Unver, 2017:18) [6].

Some Javanese cultural terms are borrowed by the translator, and some of them are used without any additional explanation. They sound foreign for target readers who are distant from Javanese cultures. Consequently, the translation sounds unnatural since there are Javanese terms that are foreign for the target readers. The terms also confuse readers since they do not have any background knowledge about the term. It means that the borrowed cultural terms make the translation not only unnatural but also difficult to understand.

The above facts have shown that the translator has not played his/her role well. The translator of the Radya Pustaka Museum brochure as one of the forms of tourism promotional discourse has a role "... to produce an effective translation in the target language and culture in order to persuade potential tourists in that language and culture." (Sulaiman, 2014) [7].

The above analysis also shows that the source text is not well structured. Run-on sentences and ambiguous phrases are found. The translator, unfortunately, tends to be closely attached to the style of the source text. The strong attachment to the source text style results in translation which is considered to be difficult to understand by target readers. It is true that the translator of Radya Pustaka Museum brochure has a thorny job since s/he has to make the translation corresponds with the original while at the same time s/he has to be able to present the objects of the museum which are culturally-bound to non-native readers who have no previous knowledge about them. Considering that the translator has a role as a communicator (Hatim and Mason, 1997), s/he needs to be more detached to the source text style when it is not well structured [8]. 
These findings can lead to an implication the translation of the museum's brochure has not yet achieved its purpose, i.e. inviting readers to come and do further study on what is offered by the museum. The findings and discussion also suggest that one of the essential factors in conveying persuasion is readers (targets)' comprehension of text. Without comprehension, interest will not likely to be generated in the mind of readers.

\section{Conclusion}

Based on the analysis, problems in the English version of Radya Pustaka Museum brochure are identified. The problems can be classified into linguistic aspects and cultural aspects. The linguistic aspects cover syntactic problems and semantic problems and the cultural aspects deal with the use of Javanese terms and concepts. All these end up in the decrease of the level of naturalness and obstacles complicating readers' comprehension. This study uncovers that conformity to the norms in the target language and culture and proper treatment of source language cultural items are essential in the production of quality translation involving cultural differences.

\section{References}

[1] Sari, J. A.\& Antoni, D. (n.d.). Menerjemahkan teks turisme kesulitan dan strateginya. Retrieved Pebruari 3 , 2020, from https://docplayer.info/53017332Menerjemahkan-teks-turisme-kesulitan-dan-strateginya-oleh-j-a-sari-dosen-pada-stpsahid-surakarta.html

[2] Shehab, Nahedah Hashim Abu. (2011). Translating brochures advertising personal care products from english into arabic: Strategies and linguistic inaccuracy (master's thesis). An-Najah National University, Nablus, Palestina.

[3] Sulaiman, Mohamed Zain. (2016). The misunderstood concept of translation in tourism promotion. Translation and Interpreting, 8(1), 53-68. https://doi.org/10.12807/ti.108201.2016.a04

[4] Ornia, G. F. (2015). Medical brochures translated into English and their comparison with source English and Spanish medical mrochures. Procedia - Social and Behavioral Sciences 212, 226-229

[5] Master, Peter (2013) 'A Contrastive Study of Determiner Usage in EST Research Articles'. International Journal of Language Studies , 7(1), 33-58

[6] Unver, Meral M (2017) On Voice In English: An Awareness Raising Attempt on Passive Voice. European Journal of Foreign Language Teaching. Volume 2. Issue 3. 2017. 17-29

[7] Sulaiman, Mohamed Zain (2014). 'Translating the Style of Tourism Promotional Discourse: A Cross Cultural Journey into Stylescapes'. Procedia - Social and Behavioral Sciences 118. 503-510

[8] Hatim, Basil \& Ian Mason. (1997). The Translator as Communicator. London: Routledge 